ROKSANA CHOWANIEC,

University of Warsaw, Institute of Archaeology,

Warsaw, Poland

email: roksana.chowaniec@uw.edu.pl

MATERA MARCIN,

University of Warsaw, Institute of Archaeology,

Warsaw, Poland
UDC: 904:738.6”652”(450.82);

902.2(450.82)”2010”

Original research article

Received: May $13^{\text {th }} 2013$

Accepted: October $15^{\text {th }} 2013$

\title{
NEW TERRACOTTA FIGURINE OF DEMETER/CERES FROM THE SOUTH-EASTERN SICILY
}

\begin{abstract}
On a southern hill slope facing the Tellaro River valley, in the autumn of 2010 during a field survey, the new female terracotta figurine has been found. The figure can be interpreted as a representation of the goddess Demeter/Ceres, whose cult was very common in Sicily. However newly discovered terracotta coming from a context dated by the accompanying ceramic assemblage to the Middle Imperial period.
\end{abstract}

Keywords: terracotta figurine, Demeter/Ceres, field survey, pottery, cult.

To a dynamically developing Rome the island of Sicily appeared tempting as much for its fertile land as for, and perhaps foremost, its strategic location. Conquering it and other islands on the Mediterranean Sea weakened Carthage, Rome's biggest rival in the 3rd century BC. (Bringmann 2007: 107-108). According to the relation between Rome and local cultures on Sicily cf. Language and Linguistic Contacts in Ancient Sicily, O. Tribulato (ed.), Cambridge 2012; Wilson R.J.A., Hellenistic Sicily, c. 270-100 BC, in The Hellenistic West. Rethinking in Ancient Mediterranean, J.W.W. Prag, Quinn J.C. (eds.), Cambridge 2013, 79-119.

Upon closer investigation of historical and archaeological sources, the seemingly well studied history of the first Roman provincia reveals many gaps and uncertainties. These are due mostly to the state of research, but also to meagre scholarly interest in the archaeology of Sicily after the Punic wars. There are multiple unanswered questions, like how did the Greek colonies change after the 212-210 BC, the year that Marcus Claudius Marcellus sealed the conquest of Sicily? (The military operation followed a renouncement of the alliance with Rome by Hieronymus, ruler of Syracuse, successor and grandson of Hiero II, who had sought instead the help of the enemy in Carthage.) How was the island's economy restructured after that? Did the new, foreign, Roman administration and the presence of Rome in an agriculturally rich Sicily turn cities into rural centres and the countryside into a food resource? What did direct subordination to Roman authority mean for the Greek colonies and was Roman rule effective enough to penetrate island structures?

From Cicero we know that in Sicily the Romans experimented with governing newly conquered peoples, learning how to dominate by trial and error (Cicero II.1.2; cf also Clemente 1980: 
105; Zambon 2008). First and foremost, officials were dispatched to Sicily and Sardinia already in 227 BC, swelling thus the praetors' ranks. By the end of the Second Punic War Rome's control over Sicily was judged firm enough for the praetor's role to be reduced to administration, legislation, and tax collection. However, the island remained proud and in a sense it retained its independence with local traditions lingering in the shadow of Roman expansion. For example, Greek remained Sicily's commonly spoken tongue until the end of the 1st century BC (Fraschetti 1981: 51-77; Wilson 1990a: 67), and perhaps even longer, despite the Roman conquest. ${ }^{1}$ Greek models of civic organisation, literature and law were adopted by Roman colonists (on lasting Greek traditions, cf.: Vermeule 1977; Gazda and Haeckl (ed.) 1994) and the works of Greek historians: Timaios of Tauromenion (modern Taormina) and Philinos of Akragas (modern Agrigento) continued to be the main sources for studying Roman history (Bringmann 2007: 118, no. 2). Moreover, the Greek heritage influenced Roman culture and religion. ${ }^{2}$ Romans banned participation in ceremonies dedicated to foreign cults, but in practice it was impossible to control the enforcement of this law, especially in distant Sicily, where the attitude towards the Roman state was fairly anarchistic in many places.

Most likely, lasting Greek religious customs and their influence on Roman culture appear to be exemplified by a newly discovered terracotta figurine 'coming' from a context of the other pottery finds, dated to the Middle Imperial period. The site is situated not far from Contrada Granieri-Contrada Olia (Alia)-Contrada Sbriulia, com. Noto, prov. Siracusa, south of Valle Ruglia. It was found in the autumn of $2010^{3}$ during a field survey carried out with appropriate

\footnotetext{
1 Also Latin inscriptions are practically absent from Sicily prior to the invasion by Sextus Pompeius, cf. Wilson 1990: 30. New evidence Tribulato O., Siculi bilingues? Latin in the inscriptions of early Roman Sicily, in Language and Linguistic Contacts in Ancient Sicily, O. Tribulato (ed.), Cambridge 2012, 291-325.

2 E.g. the introduction of the cult of Cybele in Rome already at the end of the Second Punic War or the diffusion of the cult of Aphrodite of Eryx (Erice) in 215 BC (cf: Spaeth 1996: 12-13).

3 The researches have been possible thanks to the grant of the National Science Centre (N N109 104940), as well as private sponsors.
}

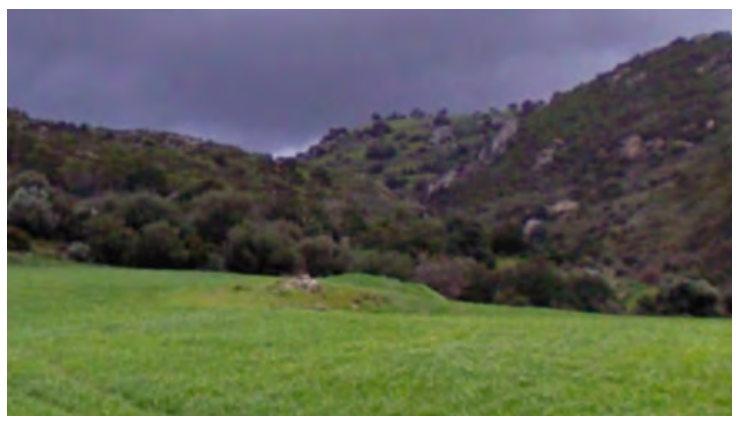

Fig. 1 The view on the site and neighborhood

permits on the grounds of an agreement signed between the Institute of Archaeology of the University of Warsaw and Soprintendenza dei Beni Culturali e Ambientali di Siracusa ${ }^{4}$ represented by the Director of the Servizio Beni Archeologici Dr Rosa Lanteri ${ }^{5}$. The site lies on a southern hill slope facing the Tellaro River valley. It is exposed ground with a gradient reaching 45 degrees (Fig. 1). The uncovered finds must have been washed down the slope from the summit and were dispersed evenly over an area of 120 ares. The nature of the finds and the location indicate that the site was a settlement. It may have been a farm, which would hardly come as a surprise, given the fertility of the surrounding land.

The female terracotta figurine is preserved from the thighs up (Fig. 2). The uncovered fragment measures $14.4 \mathrm{~cm}$ in height and a maximum of $0.9 \mathrm{~cm}$ in width. The clay is light beige with dark pink core, containing medium-grained inclusions of limestone and quartz. The outer surface of the statuette is somewhat porous and severely calcified. The figure portrays a standing female. Her right hand holds a 'torch' vertically against the right side of her body, the upper part of the object resting against her shoulder. Simplified features can be distinguished in the oval face. The tall headdress, polos, on her head terminates in a veil that flows to the shoulders and is clearly visible in front. The figure is clad most probably in a long dress (chiton?) and a shawl, epiblema, draped around the shoulders. The terracotta was mouldmade and is hollow inside. The back is slightly

4 The documentation and artifact have been presented immediately to the Soprintendenza dei Beni Culturali e Ambientali di Siracusa.

5 I would like to thank warmly all the participants of the 2010 season at Akrai. Special sincere thanks I would like to dedicate for Dr Rosa Lanteri and Marta Fituła (R.CH.). 


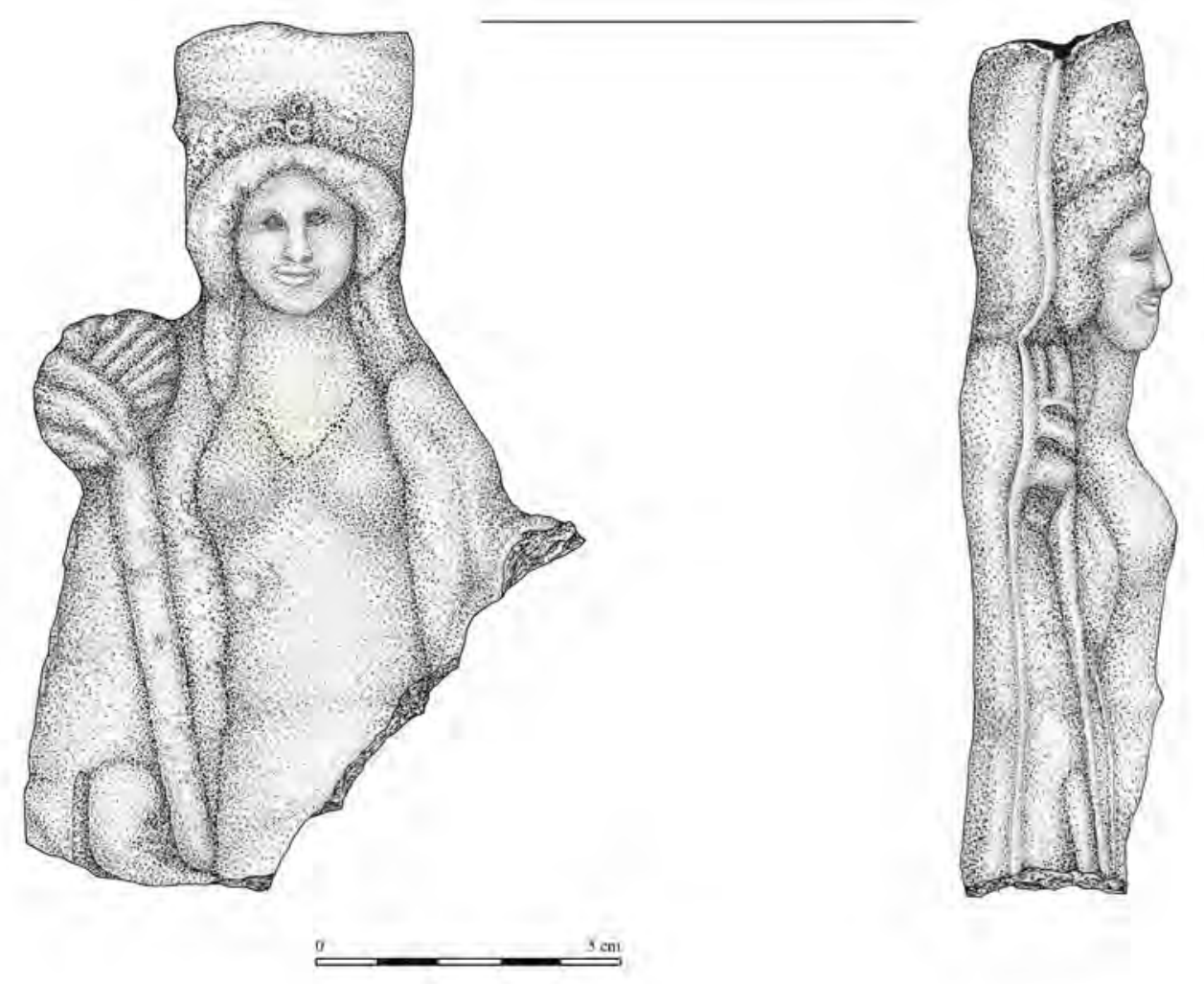

Fig. 2 The new terracotta figurine. Draw by P. Szczęsnowicz and K. Dejtrowska

convex and there is an oval opening on the left side in the middle (fragmentarily preserved). The base, on which the figurine had once stood, is not preserved. The terracotta has been made roughly and the drawing of details is imprecisely.

The figure could be interpreted as a representation of the goddess Demeter/Ceres, whose cult was very common in Sicily (cf. Hinz 1998). The cult of Demeter, in Rome referred to as Ceres, Mother Earth, a goddess of nature, good harvest and fertility, and especially of cereals, was particularly popular on the island (cf. for example: Ciacieri 1895; Gentili 1959-1960; Voza 1976-1977; Polacco 1986 and many others). These beliefs did not have much in common with the original mother-goddess cult. The Sicilian cult had especially importance in regions ${ }^{6}$ where agriculture had always constituted the foundation of the local economy, as well as on very specially religion

6 Cult of Demeter and Kore sporadically appeared as a civic gods, except Thebes and Sicily and Magna Graecia (cf. Larson 2007: 69) and political situation in each colony. Imitations of Eleusinian Mysteries were organised throughout the Greek world (Kubiak 1999: 218-219). Demeter as the bringer of seasons was also exalted in poetry, an example of which is a Homeric hymn in her praise: I begin to sing of Demeter, the holy goddess with the beautiful hair (...) Lady Demeter, bringer of hôrai, giver of splendid gifts (Foley 1994). The goddess was also the subject of writings by Diodorus Siculus (V.1-3) and Cicero (II.4.106), who described her cult in Sicily, Ovid, who pointed out the existence of a lively cult centre of Demeter in a meadow near the city of Henna (modern-day Enna), as well Claudius Claudianus of Alexandria, who set the plot of his De raptu Proserpinae on the island. The repeated descriptions gave life to a conviction, supported by the remarkably fertile soil on the island, that Demeter was of Sicilian origin (Sacks 1995: 107). Myths referring to her origin were created generally throughout the Greek world, but Sicily was a favoured location (Ciaceri 1911). However some 
accounts claim that she arrived from Crete (Nonni Panopolitani Dionysiaca 6. 121; cf also: Kerényi 2002: 209). In the context of Sicily, Demeter is described as the one who contended with Hephaestus for rule of the island and control over Etna (Grimal 1987: 71).

The presence of Demeter was connected with good harvests, and her absence from the land with catastrophes and infertility of the land (for more on the cult of Demeter, cf. Larson 2007: 69-76). For this reason the ancients sought her favour by establishing cult places, which were often located practically in the wilderness, for instance, in forests or on rocky cliffs ${ }^{7}$. The Greek world offered Demeter cows, honey and fruit, while the Romans brought her corn ears, fruit and pigs. The goddess was portrayed as a beautiful, mature woman. Her most common representation is a figure, standing or seated, with a sad face, dressed in a chiton and an outer garment (himation or epiblema), wearing a wreath of corn ears (corona spicea), polos, kalathos or veil, or with hair tied with a ribbon, holding a torch, corn ears, scythe, jug, fruit or sceptre. Her attributes included a narcissus or poppy; her favourite bird was a crane and her preferred offering a pig. The described representations of Demeter correspond very well with how the goddess (Raffiotta 2007: 61-66, tabl. 13:54-57, 14:60-61) was depicted in the figure from Contrada Granieri-Contrada Olia (Alia)-Contrada Sbriulia.

The same site also yielded numerous ceramic vessel fragments, including a few dozen sherds of amphorae, tableware and kitchenware. The context was dated by the toe of an Africana Grande IIB amphora ${ }^{8}$ (Fig. 3a) and the rim of an

7 The places devoted to the Demeter's cult can be simply identified by the votive artifacts as pottery, terracottas of standing women holding torches and piglets, olive lamps, clay pomegranates (Larson 2007: 70, 83).

8 Amphorae of the mentioned type were classified on the grounds of finds from Ostia as type III - Ostia III, cf. Panella 1973: 580. F. Zevi and A. Tchernia distinguished two variants of the same type of vessels referred to as Africana I Piccolo and Africana II Grande, and the latter was divided by C. Panella into four subgroups: IIA, IIB, IIC and IID, cf. Zevi, Tchernia 1969: 173-180; Panella 1972: 98, fig. 61-62; Panella 1973: 580-582; Manacorda 1977: 124-125. In S. J. Keay's typology, the Africana Grande IIB amphora type was designated as VBis, cf. Keay 1984: 115-118. In some publications the applied typology does not include the subdivisions proposed by C. Panella, cf.
African Red Slip Ware form 32/58 according to J. W. Hayes (Fig. 3b). The dating of Africana II Grande amphora types falls within the period from the end of the 2nd century AD to the 4th/5th century AD (Keay 1984: 116, 392, no 18; Peacock 1986: 156, no 18; and on 3rd - beginning of $5^{\text {th }}$ AD cf. Sciallano, Sibella 1991: 81, no 18). ${ }^{9}$ As for the ARSW vessel form 32/58, it is dated to the end of the 3rd-early 4th century AD (Hayes 1972: 96).

Beside the abovementioned forms, fragments of amphorae types 20 (Fig. 3c) and 23 (Fig. $3 d)$ in H. Dressel's typology were also identified (CIL XV, 2, tabl. 2). Dressel 20 amphorae $^{10}$ are also referred to in the literature as Camulodunum 187 (Hawkes, Hull 1947: 252-253), Callender 11 (Callender 1965: 19-20), Beltrán V (Beltrán

Beltrán Lloris 1970: 549-556, type 56; Peacock, Williams 1986: 155-157, class 34; Sciallano, Sibella 1991: 81; Dyczek 1999: 153-157, type 26 (English edition: Dyczek 2001: 194-198, type 26); Paraschiv 2006: 124-125, type 5 9 The earliest examples come from a shipwreck discovered off the coast of Monaco, where they appeared in a context dated from the end of the 2nd century AD to the first quarter of the 4th century AD, cf. Mouchot 1968-1969: 159; Keay 1984: 116; Panella 1983: 235. The earliest examples of Africana Grande IIB amphorae from Ostia are dated to AD 230-250, cf. Panella 1983: 586 sq, no. 18. C. Raynaud and M. Bonifay date these amphorae to AD 220-320 (Raynaud, Bonifay 1993: 17). D. Manacorda supplies information on this type of amphorae identified in layers dated to the 4th and early 5th century AD (Manacorda 1977: 162 sq, no. 18). 10 In H. Dressel's typology created on the basis of finds from Monte Testaccio different variants of vessels were erroneously distinguished as two separate forms, Dressel 20 and Dressel 25; cf. Dyczek 1999: 76; Dyczek 2001: 93-94. Excavations on sites in Colonia Augusta Rauricorum and Castrum Rauracense verified the typology of the Dressel 25 type. The form was established as the earliest of the variants of Dressel 20 vessels and designated as Dressel 20A: Martin-Kilcher 1983: 53-54. In spite of this some researchers still distinguish Dressel 25 amphorae as a separate form: Paraschiv 2006: 62-64, no. 18, type 23 (Dressel 25) and type 24 (Dressel 20). In the cumulative typology of D. P. S. Peacock and D. F. Williams this form was classified as type 24: Peacock, Williams 1986: 134-135, no 18, class 24. Amphorae of this type are common finds on the limes Germanicum. Various designations are applied to this form found in the region of Germania: Haltern 71: Loeschcke 1909: 257-258; Hofheim 76: Ritterling 1913: 302-305, Figs. 73-74; Niederbieber 78: Oelmann 1914: 65-66, Fig. 48; Oberaden 83: Albrecht 1942: Pl. 35, 83; Gose 1950: 38, Pl. 61, nr. 439-442; and Rödgen 70: Schönberger, Simon 1976: 113, 195. 


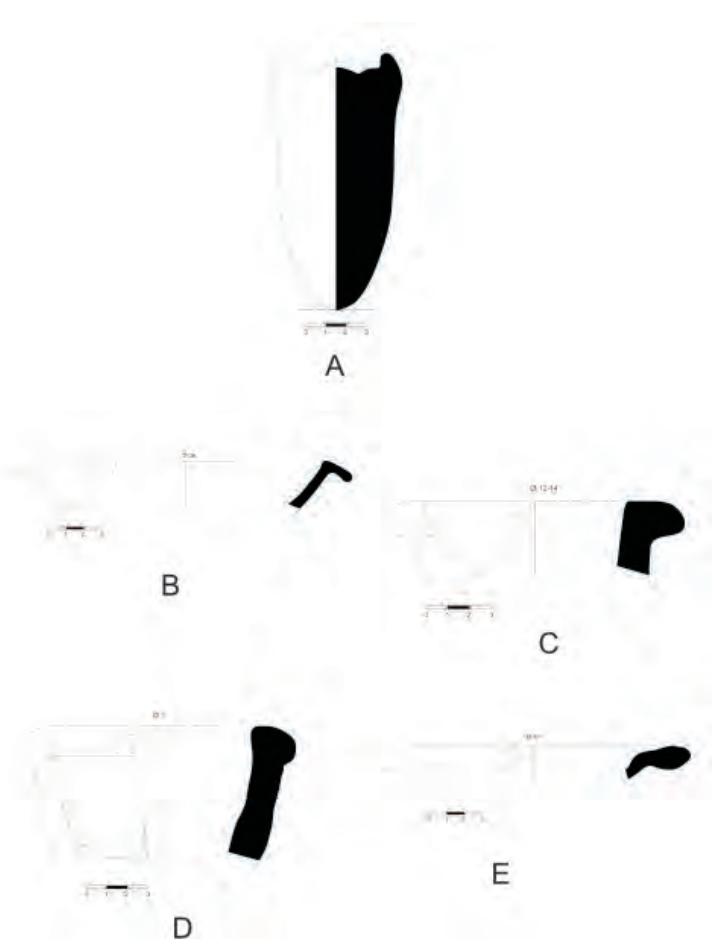

Fig. 3 The pottery finds. Draw by M. Woińska

Lloris 1970: 464-492, no 18), Ostia I (Panella 1970: 108-109: Panella 1983: 522-535), Peacock and Williams class 25 (Peacock, Williams 1986: 136-140, no 18), Kelemen 18 (Kelemen 1990: 160-171), Bjelajac VIII (Bjelajac 1996: 33-35), Dyczek 8 (Dyczek 1999: 76-81; Dyczek 2001: 93-99), and Paraschiv 24 (Paraschiv 2006: 62-64, no 18). Their dating (including Dressel 25 amphora types) spans a period from the end of the 1 st century BC to the second half of the 3rd century AD (Peacock, Williams 1986: 135-136, no 18; Sciallano, Sibella 1991: 65, no 18). ${ }^{11}$ Considering the formal traits of their morphology, Dressel 23 amphorae should be genealogically associated with the Dressel 20 form discussed above (Beltrán Lloris 1970: 514-517, no 18; Remesal Rodríguez 1983: 119, 125; Martin-Kilcher 1987: 337-348, no 32; Keay 1984: 140, no 18; Remesal Rodríguez 1989: 121-153). In the literature on the sub-

11 Although according to D. Manacorda these amphorae occurred sporadically even in the 4th century, cf. Manacorda 1977: 135 sq, no 18). According to the classification proposed by S. Martin-Kilcher, individual variants of Dressel 20 amphorae are dated as follows: Dressel 20A: 10 BC - AD 30; Dressel 20B: 30 BC - AD 50; Dressel 20C: AD 50-70; Dressel 20D: AD 70-110; Dressel 20E: AD 110-150; Dressel 20F: AD 150-210; Dressel 20G: AD 210-280 (Martin-Kichler 1987: 53-58 and annexes 1-2; Raynaud 1993: 25-26). ject they are also referred to as: Keay XIII (Keay 1984: 140-146, no 18), ${ }^{12}$ Peacock, Williams class 26 (Peacock, Williams 1986: 14, no 18), Bjelajac IX (Bjelajac 1996: 35-36, no 29), and Paraschiv 25 (Paraschiv 2006: 64-65, no 18). S. MartinKilcher classified this form of amphora as variant $\mathrm{H}$ of the Dressel 20 type (Martin-Kilcher 1987: 56, no 32). The beginnings of production of Dressel 23 amphorae go back as far as the beginning of the 3rd century AD (Manacorda 1977: $137 \mathrm{sq).}{ }^{13}$ This amphora type went out of use in the late 6th and early 7th century AD (Keay 1984: 142, no 18).

A rim fragment from a grey ware bowl, most likely an imitation in form of Late Roman red-slip ware (Fig. 3e), completes the ceramic assemblage of finds.

The bulk of the pottery from the site in question sets its chronology provisionally in the 3rd4th century AD. The dating is certain, although surprising given the find of the terracotta figurine of Demeter/Ceres. To be sure, multiple phasing of the site cannot be excluded, in which case the surface pottery finds will not date the context fully. We also can not disqualify that the terracotta went downhill or has been redeposited here from somewhere else in the neighborhood. It is also probable, however, that the figure could reflect lasting Greek traditions in the realities of Roman Sicily, especially its south-eastern part, where according to the literary and archaeological evidence the cult of Demeter was deeply rooted and where Roman Ceres could show the iconography of Greek Demeter (Voza 1976-1977: 556-559; Hinz 1988: no 7; Shapiro 2002: 82-95; Greco 2002: 110-118; di Stefano ed. 2008). The longevity of the cult of Demeter is proven by numerous mentions in written sources and by the archaeological record. Already from the beginning of the 3rd century BC, and especially in the 2nd century BC, under the influence of Hellenistic cities and Greek heritage, the cult of Ceres gained popularity among Roman women and attributes of Demeter were adopted for the iconography of Ceres (Spaeth 1996: 11).

12 S. J. Keay divided this type of amphora into five variants (A to E). M. Beltrán Lloris proposed two variants A-B (Beltrán Lloris 1970: 514-517, no 18). 13 D. Manacorda also discusses fragments of this type of amphorae from Ostia, dated to the first and second quarters of the 3rd century AD. 
Livy reported that after the battle of Cannae the City was thrown into such universal mourning that the annual celebration of the festival of Ceres was suspended (Livy V, 22.56.4).

Cicero, already referred to above, wrote that insulam Siciliam totam esse Cerei et Liberae consecrata, and the non-Greek inhabitants of Sicily considered it absolutely natural (Cicero II.4.111, no 2). ${ }^{14}$ An inscription from the vicinity of Avola in prov. Siracusa, dated to the 1st century BC, shows that Roman settlers engaged as prostatai in local cults of Demeter together with the local population (Manganaro 1976 (1985): 159; Wilson 1990b: 29, 30, no 4; Manganaro 1996: 79). The lasting cult of Demeter/Ceres was connected not only with deeply rooted agrarian traditions, but also specifically with grain shipped from Sicily to Rome ( Bell 1972; Bell 1981: 97). Therefore, with the fall of the Republic, when Sicilian produce (including grain) ceased to play as important a role (Erdkamp 2005: 209-225), the cult goddess witnessed a decline. The dwindling importance of a major cult centre in Enna (more about Enna cult cf. Schipporeit 2008), visited still in 133 BC by official delegations of Roman officials bearing offerings to the goddess, illustrates these processes (Wilson 1990b: 288; de Miro 2000: 90). Coins bearing an image of the goddess were struck here until the end of the 1st century $\mathrm{BC}^{15}$ and the presence of an inscription mentioning a sacerdos Cereris, dated to the early 2nd century AD, testifies to the persistence of the cult, albeit on a local scale (Wilson 1990b: 288, no 4). ${ }^{16}$

Traditional cults were also upheld in other regions. During the Imperial period the festival of Ceres was celebrated in Catania, Halaesa, on Malta, in Palermo and Taormina (about tradition cf. de Miro 2000: 90). Probably also the inscription dated to the 1st century AD found in Palermo has been dedicated to Ceres as well as dedication of

14 On the cult of Ceres on Sicily cf. Cicero II.4.99 and II.5.187. Describing the Silician-Roman cults, Cicero focused mostly on Ceres, omitting many other deities and stressing that she was of lesser importance to the Romans than to the Greeks (Frazel 2009: 84).

15 Obv. Veiled head of Ceres with corn ears l.; Rev.: Pluto and Proserpina in quadriga r. Inscription: L MVNATIVS M CESTIVS; Enna; 44/36 BC (RIC 1992: 177, Pl. 39:661, type 661; Caltabiano 2008: 127-128) 16 It may be testimony of a lasting tradition or of copying information on the cult from earlier sources. priest from Tindaris dated to middle of Imperial period (Wilson 1990b: 289). The festival of Ceres in Catania was described by Lucius Caecilius Firmianus Lactantius (ca. 240-ca. 320), who rendered the Catanian festivities equal to the religious feast at Enna. The celebration in Catania took place on 16 August, as confirmed by a Latin graffito from the $1 \mathrm{st} / 2$ nd century AD found in the eastern part of the city, along Vittorio Emanuele street (Santangelo 1919-1920: 174:180). The survival of beliefs is also visible in archaeological material, for instance in the form of finds of Centuripe statues from the 2nd century AD (Patané 2011: 51-52, fig. 43-45) or a production centre of statues of this goddess in Halaesa from the turn of the 2nd century $A D$ (Wilson 1990: 289, no 4). The figure from Contrada Granieri-Contrada Olia (Alia)-Contrada Sbriulia may have been placed in a household shrine and used for an extended time.

We have also some evidence of Ceres in the iconography outside of Sicily, where Ceres hold the classic attributes of Demeter, for example a bronze statute dated to the 2nd-3rd century $\mathrm{AD}$ from collection of Bibliothèque National de France in Paris (Spaeth 1996: 23, fig. 12).

In a sense, the cult of the goddess lasted and lasts until today. In medieval time the story of Grain Maiden of Milan could be connected with the Demeter/Ceres (Spaeth 1996: 31). As late as in the 19th century the farmers from the vicinity of Eleusis decorated statues of Demeter with flowers to ensure a good harvest. Perhaps the feast of Our Lady of the Herbs, ${ }^{17}$ celebrated [in Poland] on 15 August, could also be a relic of a Demeter cult.

\section{BIBLIOGRAPHY}

\section{Bell, M. 1972}

The terracottas of Morgantina 400-50 B.C., Michigan: Ann Arbor.

\section{Bell, M. 1981}

The Terracottas. Morgantina Studies. Volume 1., Princeton-New Jersey: Princeton University Press.

17 This feast is celebrated since the 5th century AD. In Poland it is Our Lady of the Herbs, in Germany, of the Flowers; in Estonia, of the Rye and in the Czech Republic, of the Spices. 
Beltrán Lloris, M. 1970

Las anforas romanas en España, Zaragoza: Institución Fernando el Católico.

\section{Bjelajac, L. 1996}

Amfore gornjo mezijskog Podunavlja, Beograd: Arheoloski Institut.

\section{Bringmann, K. 2007}

A History of the Roman Republic, Cambridge: Polity Press.

\section{Callender, M. H. 1965}

Roman Amphorae with Index of Stamps, LondonNey York: Oxford University Press.

Caltabiano, C. M. 2008

Il 'ruolo; di Demetra nel document monetale greco, in: Demetra. La divinità, i santuari, il culto, la leggenda. Di Stefano C. A. (ed.). Atti del I Congresso Internazionale, Enna, 1-4 luglio 2004. Pisa-Roma: Fabrizio Serra Editore, 123-134.

Ciaceri, E. 1895

Il culto di Demetra e Kore nell'antica Sicilia, Catania: Brancato Editore.

\section{Ciaceri, E. 1911}

Culti e miti nella storia dell'antica Sicilia, Catania: F. Battiato.

\section{Clemente, G. 1988}

Sicily and Rome. The Impact of Empire on a Roman Province, in: Forms of Control and Subordination in Antiquity. Yuge T., Doi M. (eds.). Proceeding of the International Symposium for Studies on Ancient World, January 1986, Tokyo. Leiden-New York-København-Köln: The Society for Studies on Resistance Movements and E. J., Brill, 105-120.

De Miro, E. 2000

Agrigento. I. I santuari urbani. L'area sacra tra il tempio di Zeus e porta V, Roma: L'Erma di Bretschneider.

\section{Di Stefano, A. C. (ed.) 2008}

Demetra. La divinità, $i$ santuari, il culto, la leggenda. Atti del I Congresso Internazionale, Enna, 1-4 luglio 2004. Pisa-Roma: Fabrizio Serra.

\section{Dyczek, P. 1999}

Amfory rzymskie z obszaru dolnego Dunaju. Dystrybucja amfor $i$ transportowanych $w$ nich produktów w I-III w. po Chr., Warszawa: Instytut Archeologii Uniwersytetu Warszawskiego.

\section{Dyczek, P. 2001}

Roman Amphorae of the 1st-3rd Centuries AD Found on the Lower Danube. Typology, Warsaw: Wydawnictwa Uniwersytetu Warszawskiego.

\section{Erdkamp, P. 2005}

The Grain Market in the Roman Empire. A Social, Political, and Economic Study, Cambridge: Cambridge University Press.

\section{Fraschetti A. 1981}

Per una prosopografia dello sfruttamento: Romani e Italici in Sicilia (212-44 a.c), in: Società romana e produzione schiavistica. I. L'Italia: insediamenti e forme economiche, Giardina A., Schiavone A. (eds.). Rome-Bari: Laterza, 51-77

Frazel, T. D. 2009

The Rhetoric of Cicero's In Verrem. Hypomnemata 179. Göttingen: Vandenhoeck \& Ruprecht.

Gazda, E. K. and Haeckl, A. E. (ed.) 1994

Roman Art in the Private Sphere. New Perspective on the Architecture and Decor of the Domus, Villa, and Insula, Michigan: University of Michigan Press.

\section{Gose, E. 1950}

Gefässtypen der römischen Keramik im Rheinland, Beihefte der Bonner Jahrbücher 1, Kevelaer: Butzon \& Bercker.

\section{Greco, E. 2002}

Sanctuaries of Magna Graecia and Sicily, in: Magna Graecia. Greek Art from South Italy and Sicily, Bennett M.J., Paul J. (eds.). New York: Cleveland Museum of Art, 98-119.

\section{Grimal, P. 1987}

Stownik mitologii greckiej i rzymskiej, WrocławWarszawa-Kraków-Gdańsk-Lódź: Zakład Narodowy im. Ossolińskich. 
Hawkes, C. F. C. and Hull, M. R. 1947

Camulodunum. First Report on the Excavations at Colchester 1930-1939, Reports of Research Committee of the Society of Antiquaries of London 14, Oxford-London: Society of Antiquaries.

Hayes, J. W. 1972

Late Roman Pottery, London: British School at Rome.

\section{Hinz, V. 1988}

Der Kult von Demeter und Kore auf Sizilien und der Magna Graecia, Palilia 4, Wiesbaden: Dr Ludwig Reichard. Verlag.

Keay, S. J. 1984

Late Roman Amphorae in the Western Mediterranean. A typology and economic study: the Catalan evidence, British Archaeological Reports International Series, vol. I, 196, Oxford: Archaeopress.

Kelemen, M. H. 1990

Roman Amphorae in Pannonia III, Acta Archaeologica Academiae Scientiarum Hungaricae 42: 147-193.

Kerényi, K. 2002

Mitologia Greków, Warszawa: Wydawnictwo KR.

Kubiak, Z. 1999

Mitologia Greków i Rzymian, Warszawa: Wydawnictwo Świat Książki.

\section{Larson, J. 2007}

Ancient Greek Cults. A Guide, New York-London: Routledge.

\section{Loeschcke, S. 1909}

Keramische Funde in Haltern. Ein Beitrag zur Geschichte der augusteischen Kultur in Deutschland, Mitteilungen der Altertums-Kommission für Westfalen 5: 101-322.

\section{Manacorda, D. 1977}

Anfore, in: Ostia IV, Le terme del Nuotatore. Scavo dell'ambiente $X V I$ e dell'area $X X V$. Carandini A., Panella C. (eds.). Studi Miscellanei 23, 116265.
Manganaro, G. 1976 (1985)

Il tempio greco in Sicilia. Architettura e culti, Atti della Ia riunione scientifica della scuola di perfezionamento in archeologia classica dell'Università di Catania, Siracusa, 24-27 Novembre 1976, Contributi dell'Istituto di Storia Antica dell'Università di Milano XVI: 148-164.

\section{Manganaro, G. 1996}

Figurazioni e dediche religiose della Sicilia greca e romana, Zeitschrift für Papyrologie und Epigraphik 113: 77-81.

\section{Martin-Kilcher, S. 1983}

Les amphores romaines à huile de Bétique (Dressel 20 et 23) d'Augst (Colonia Augusta Rauricorum) et Kaiseraugst (Castrum Rauracense). Un rapport préliminaire, in: Produccion y comercio del aceite en la Antigüedad. Segundo Congreso Internacional (Sevilla, 24-28 Febrero 1982), Blázquez Martínez J. M. and Remesal Rodríguez J. (eds.), Madrid: Universidad Complutense, 337-347.

\section{Martin-Kilcher, S. 1987}

Die römischen Amphoren aus Augst und Kaiseraugst. Ein Beitrag zur römischen Handels und Kulturgeschichte 1: Die Südspanischen ölamphoren (gruppe 1). Forschungen in Augst 7, Augst: Römermuseum.

\section{Mouchot, D. 1968-1969}

Épave romaine 'A' du port de Monaco, Bulletin du Musée d'Anthropologie Prehistorique de Monaco 15: 159-201.

\section{Oelmann, F. 1914}

Die Keramik des Kastells Niederbieber. Materialien zur römisch-germanischen Keramik I, Frankfurt am Main: J. Baer.

\section{Panella, C. 1970}

Anfore, in: Ostia II. Le terme del Nuotatore. Scavo dell'ambiente I, Berti F., Carandini A. and Panella C. (eds.). Studi Miscellanei 16: 102-156.

\section{Panella, C. 1972}

Annotazioni in margine alle stratigrafie dell Terme Ostiensi del Nuotatore, in: Recherches sur 
les amphores romaines, Baldacci P., Kapitän G., Lamboglia N., Panella C., Rodríguez Almeida E., Sciarra B., Tchernia A. and Zevi F. (eds.). Collection de l'cole Française de Rome 10. Paris: École Française de Rome, 69-106.

Panella, C. 1983

Appunti su un gruppo di anfore della prima, media e tarda etá imperiale, in: Ostia III. Le terme del Nuotatore. Scavi degli ambienti III, VI, VII, Carandini A. and Panella C. (eds.). Studi Miscellanei 21: 460-633.

\section{Panella, C. 1983}

I contenitori oleari presenti ad Ostia in eta' antonina: analisi tipologica, epigrafica, quantitative, in: Produccion y comercio del aceite en la Antigüedad. Segundo Congreso Internacional (Sevilla, 24-28 Febrero 1982), Blázquez Martínez J. M. and Remesal Rodríguez J. (eds.), Madrid: Universidad Complutense, 225-261.

Paraschiv, D. 2006

Amfore romane şi romano-bizantine în zona Dunării de Jos (sec. I - VII p. Chr.), Iaşi: Fundaţiei Axis.

\section{Patané, R. P. A. 2011}

Impero di Roma e passato Troiano nella società del II secolo. Il punto di vista di un famiglia di Centuripe, Quaderni del Museo Civico Lanuvino 3, Roma: Aracne.

Peacock, D. P. S. and Williams, D. F. 1986

Amphorae and the Roman Economy. An Introductory Guide, London: Longman.

\section{Raffiotta, S. 2007}

Terrecotte figurate dal santuario di San Francesco Bisconti a Morgantina, Enna: EditOpera.

\section{Raynaud, C. 1993}

Amphores de Bétique, in: Mélanges d'histoire et d'archéologie de Lattes. Dictionnaire des céramiques antiques (VIIe s. av. n.è. - VIIe de n.è.) en Méditerranée nord-occidentale (Provence, Languedoc, Ampurdan), Py M. (ed.). Lattara 6, Lattes, 23-27.
Raynaud, C. and Bonifay, M. 1993

Amphores africaines, in: Mélanges d'histoire et d'archéologie de Lattes. Dictionnaire des céramiques antiques (VIIes. av. n.è. - VIIe de n.è.) en Méditerranée nord-occidentale (Provence, Languedoc, Ampurdan), Py M. (ed.). Lattara 6, Lattes, 15-22.

\section{Remesal Rodríguez, J. 1983}

Transformaciones en la exportación del aceite bético a mediados del siglo III $d$. C., in: Producción y comercio del aceite en la Antigüedad. Segundo Congreso Internacional (Sevilla, 24-28 Febrero 1982), Blázquez Martínez J. M. and Remesal Rodríguez J. (eds.). Madrid, 115-131.

\section{Remesal Rodríguez, J. 1989}

Tres nuevos centros productores de ánforas Dressel 20 y 23. Los sellos de Lvcivs Fabivs Cilo, Ariadna 6: 121-153.

\section{Ritterling, E. 1913}

Das frührömische Lager bei Hofheim im Taunus, Annalen des Vereins für Nassauische Altertumskunde und Geschichtsforschung 40, 1912, Wiesbaden: Bechtold, 302-305.

\section{RIC 1992}

Roman Provincial Coinage I. From Death of Caesar to the Death of Vitellius (44 BC-AD 69), vol. 1, Burnett A., Amandry M. and Ripollès P. P. (eds.), London: British Museum Press and Bibliothèque Nationale.

\section{Sacks, D. 1995}

Encyclopedia of the Ancient Greek World, New York: Facts on File.

\section{Santangelo, S. 19119-1920}

Il graffito catanese e la festa do Cerere, Archivo Storico per la Sicilia Orientale XVI-XVII: 174180.

Schipporeit S., Enna and Eleusis, in: Demetra. La divinità, $i$ santuari, il culto, la leggenda. Di Stefano C. A. (ed.). Atti del I Congresso Internazionale, Enna, 1-4 luglio 2004. Pisa-Roma: Fabrizio Serra Editore, 41-46. 
Schönberger, H. and Simon, G.-H. 1976

Das Augusteische Römerlager Rödgen. Die Funde aus den frühkaiserzeitlichen Lagern Rödgen, Friedberg und Bad Nauheim, Limesforschungen 15, Berlin: Gebr. Mann.

Sciallano, M. and Sibella, P. 1991

Amphores. Comment les identifier?, Aix-enProvence: Edisud.

\section{Shapiro, H. A. 2002}

Demeter and Persephone in Western Greece: Migration of Myth and Cult, in: Magna Graecia. Greek Art from South Italy and Sicily, Bennett M. J., Paul J., Iozzo M. and White B. M. (eds.). New York: Hudson Hills Press, 82-95.

Spaeth, B. S. 1996

The Roman Goddess Ceres, Austin: University of Texas Press.

\section{Wilson, R. J. A. 1990a}

Roman Architecture in a Greek World: the Example of Sicily, in: Architecture and Architectural Sculpture in the Roman Empire, Henig M. (ed.). Oxford University Committee for Archaeology, Monograph 29: 67-90.

Wilson, R. J. A. 1990b

Sicily under the Roman Empire. The Archaeology of Roman Province, 36 BC-AD 535, Warminster: Aris \& Phillips.

Vermeule, C. C. 1977

Greek Sculpture and Roman Taste. The Purpose and Setting of Graeco-Roman Art in Italy and the Greek Imperial East, Ann Arbor: University of Michigan Press

Voza, G. 1976-1977

L'attività della Soprintendenza alle Antichità della Sicilia Orientale: Siracusa, Kokalos XXIIXXIII: 556-559.

Zambon, E. 2008

Tradition and Innovation: Sicily between Hellenism and Rome, Stuttgart: Franz Steiner Verlag.

Zevi, F. and Tchernia, A. 1969

Amphores Byzacène au Bas-Empire, Antiquités Africanes 3: 173-214.
Written Sources:

Cicero, The Verrine Orations. Books 1-2, vol. I, Loeb Classical Library 221, Greenwood L.H.G. trans., Cambridge 1928.

Diodorus Siculus, The Library of History, vol. III, Loeb Classical Library 340, Oldfather C.H. trans., London 1939, book V.1-3 (p. 97-105).

The Homeric Hymn to Demeter. Translation, Commentary, and Interpretive Essays, Foley $\mathrm{H}$. (ed.). Princeton 1994.

Livy, History of Rome, vol. V, books 21-22, Loeb Classical Library 233, Foster B.O. transl., London 1929.

Nonni Panopolitani Dionysiaca 6. 121, Bibliotheca Scriptorum Graecorum et Romanorum Teubneriana, Lipsiae 1909-1911.

\section{REZIME}

\section{NOVA TERAKOTA FIGURINA DEMETRE/CERERE IZ JUGOISTOČNE SICILIJE}

Ključne reči: terakota figurina, Demetra/ Cerera, terensko istraživanje, keramika, kult.

Rim je započeo svoja velika osvajanja u III veku pre nove ere i među prvim pokorenim zemljama bila je Sicilija, zahvaljujući pre svega svojoj plodnoj zemlji, ali još više strateškoj poziciji na Mediteranu. Kako je Ciceron jedanput rekao, stvarajući upravu ovde, Rimljani su učili kako da vladaju nad pokorenim narodima. Do kraja drugog Punskog rata procenjeno je da je rimska vlast dovoljno čvrsta i da nije više potrebno prisustvo pretora, pa se rimska vlast svela na nivo uprave, zakonodavstva i naplatu poreza. Ipak, Sicilija je ostala ponosna u smislu očuvanja svoje lokalne tradicije. Grčko nasleđe je uticalo na rimsku kulturu i religiju. Terakota figurina Demetre/Cerere o kojoj govorimo u ovom radu, je pravi primer koji to pokazuje.

Na južnoj padini brda, koje je okrenuto ka dolini Telaro reke, u jesen 2010 godine, tokom terenskih istraživanja, otkrivena je figurina od terakote. Figurina je protumačena kao predstava boginje Demetre/Cerere čiji je kult bio popularan na Siciliji. Prethodno već pomenuti Ciceron je 
napisao da je insulam Siciliam totam esse Cerei et Liberae consecrate i da negrčko stanovništvo Sicilije smatra to sasvim prirodno. Novi nalaz terakote potiče iz konteksta koji je keramičkim materjalom datovan u srednji carski period. 